\title{
FRENCH UNIVERSALISM IN THE 1990s
}

\section{Joan Wallach Scott}

This article tells a story about a French feminist attempt to refigure universalism in the 1990s in a movement for gender equality in politics that they called parité ${ }^{1}$ It is a story that addresses a set of questions much debated by philosophers and psychoanalysts, to say nothing of feminists: What is the relationship between anatomical difference and its symbolic representation? Is sexual difference (understood as a psychic not an anatomical reality) a fixed or mutable phenomenon? These questions are at the heart of countless theoretical debates and, for many feminists they have required "an obligatory detour via philosophy" (Schor 17). My story, following the hunch of the parité movement as well as my own disciplinary inclination, takes a different route, seeking its insights not so much in philosophy as in history.

French politics in the 1990s was full of debates about universalism. Whatever the issue-citizenship for North African immigrants, greater access to political office for women, or domestic partnership for homo-sexual couples (to take only the most prominent) - its proponents and critics framed their arguments as critiques of, appeals to, or defenses of a universalism thought to be distinctively French. And not just French, but republican. Universalism was taken to be the defining trait of the French republic, its most enduring value, its most precious asset. To accuse someone of betraying universalism was tantamount to accusing them of treason.

It is important to note that the debates about universalism in the 1990s were not confined (as they were in that period in the U.S.) to 
lofty academic circles or arcane theoretical texts. They were instead at the very center of politics: they resounded in the National Assembly and filled the pages of daily newspapers. Nor was universalism just a slogan; it was a serious (if disputed) philosophical concept. For many Americans, the high level of French political discourse is surprising, and the key role intellectuals can play in the articulation of public policy is enviable. There is no less corruption or dishonesty there than here, but there is a lot more intelligent reflection, and political strategy is more often formulated with an eye to its philosophical implications since these are a recognized part of the political stakes.

The story I want to tell here centers on a feminist movement that sought to refigure the terms of universalism in order to increase the numbers of women in elected office. The point was not to press for antidiscrimination or affirmative action measures, but to guarantee an equal number of seats for women and men. The partial realization of that goal came with the law of June 6, 2000, which requires (with typically complex variations) that half of all candidates for political office be women. The argument for parité was neither essentialist nor separatist; it was not about the particular qualities women would bring to politics, nor about the need to represent a special women's interest. Instead-and this is what has intrigued me since I began reading about it - the argument for parité was rigorously universalist.

Before I begin to tell the story of this compelling movement, however, I think it is necessary to define universalism. And I will do that with a look at its history.

French universalism in the 1990s - at least in the realm of politics was a mythologized restatement of the principles of 1789. Those who vociferously defended the values and ideals of the Republic against the threat of what was most often described as American multiculturalism saw themselves as protectors of a distinctively French conception of political representation. This conception rested on two related abstractions: that of the individual and that of the nation. The nation was the expression of the people's will, articulated by its representatives. These representatives were not (as had been the case under the Old Regime) spokesmen for various corporate interests; instead each stood for the collectivity as a whole. Unlike the American system, articulated at the same time (most famously by James Madison in the Federalist Papers), which saw legislatures as arenas of conflicting interests and defined representatives as voices for particular social and economic groups (or factions), the French system took the abstrac- 
tion of the nation as the referent for representation. Representatives did not reflect some already existing, competing entities; instead they constituted, through their actions, the singular body of the nation. And it was a nation "one and indivisible."

The ability of any citizen to stand for (to represent) the nation came from the fact that political individuals were understood to be abstracted from their social attributes (wealth, family, occupation, religion, profession). The Abbé Sièyes put it succinctly: "Democracy requires the complete sacrifice of the individual to the res publica, that is the sacrifice of the concrete being to the abstract being" (qtd. in Rosanvallon 48-49). Abstract individuals were commensurable and interchangeable units, possessing in common only that independent rationality upon which political life was thought to depend. The nation they constituted was equally abstract: not a reflection of the disparate and divisive realities of society, but a fictional entity - a unified totality, the embodiment of a disembodied "people."

The abstractions of individual and nation were the key to a distinctively French concept of universalism. They allowed the revolutionaries to substitute political equality for the corporate hierarchies of the Old Regime and republican unity for the rule of kings. And they held out a promise of universal inclusion in political life. Abstraction, after all, meant disregarding the attributes that distinguished people in their ordinary lives; by this measure, any and all individuals could be considered citizens. Indeed, as Étienne Balibar has pointed out, abstract individualism understands itself to be a fictitious universality, "not the idea that the common nature of individuals is given or already there, but rather the fact that it is produced inasmuch as particular identities are relativized and become mediations for the realization of a superior and more abstract goal" (58). In this sense, universality does not rest on the exclusion of the particular, but on (socially or politically) agreed upon indifference to certain particularities. The abstract must always take the social into account (if only to discount it) and so becomes the site of arguments about whether there can be limits to abstraction and of what these limits consist. Jacques Rancière puts it another way. Democracy, he argues, rests on a necessary tension between the abstraction of "the people" and the social reality such abstraction obscures. Democratic politics is the adjudication of the claims by various constituencies to represent or be represented as the people ("Post-Democracy" 171-78).

The tensions between the abstract and the social were present in political debate from the Revolution on. In the 1790s, Jews were 
admitted to citizenship only when they relinquished allegiance to their "nation" and became individuals for whom religion was a private matter. Clermont de Tonnerre's is the classic formulation of this principle: "We must deny everything to the Jews as a Nation, in the sense of a constituted body, and grant them everything as individuals" (qtd. in Birnbaum 242). Slaves, wage-earners, and women were initially ruled out of active citizenship because they were considered dependents and autonomy was a prerequisite for individuality. Even when dependency was redefined, when slaves were freed and wageearners enfranchised (in 1848), women remained unacceptable as citizens. This was, I argue, because the difference of sex was not considered to be susceptible to abstraction; it was irreducible, symbolic of a fundamental division or antagonism that could not be reconciled with the notion of an indivisible nation. Whenever the revolutionaries discussed women's place in the public sphere, they inevitably used corporeal imagery to justify exclusion - the body seemed to offer undeniable, commonsense evidence of unbridgeable difference. "Since when is it permitted to give up one's sex?" thundered the Jacobin Pierre-Gaspard Chaumette. "Is it to men that nature confided domestic cares? Has she given us breasts to feed our children?" (qtd. in Levy, Applewhite, and Johnson 15). Pierre-Joseph Proudhon echoed this view years later, in 1849, when he objected to feminist Jeanne Deroin's attempt to run for office. A female legislator, he quipped, made as much sense as a male wet nurse. Her reply - Show me which organ is required for the functions of the legislator and "I will concede the debate" - exposed the symbolic investments of his argument: well beyond any logical criteria or substantive discussion of the real capabilities and capacities of women, sexual difference stood for difference itself (qtd. in Tixerant 86). Not just any difference, but one so primary, so rooted in nature, so visible, that it could not be subsumed by abstraction.

There were, of course, objections to this view from feminists and other advocates of women's citizenship. There were bound to be objections. First of all, sexual difference is a site of struggle over meaning, not a set of fixed oppositions. Second, the virtue of abstract individualism is that it allows for debate about what counts as irreducible difference. But there were also alterations in the doctrine of republican universalism, which might have changed (but did not) the arguments that could be made about women. During the Third Republic, class was acknowledged to be a divisive force in the body politic, and (in part under the influence of the new discipline of sociology) the play 
of interests was admitted as a legitimate motive for choosing representatives. ${ }^{2}$ Put in other terms, the social was now represented in the political sphere. The emergence of a workers' party and the triumph of its candidates in local and national elections called into question the founding fathers' notion of a seamless "general will," but-as the defeat of attempts to institute proportional representation for political parties indicated - the nation was not reimagined as a reflection of preexisting social divisions. Even if representatives were elected by constituencies with particular interests, the nation they represented was still conceived as a singular, coherent body. And one of the marks of this singular coherence, as of the interchangeability of its individual representatives, was masculinity. When suffragist Hubertine Auclert issued a call to arms for women to organize, as workers had, to assert their interest by attaining not only the right to vote but to serve as representatives, a furious journalist impugned her motives in terms that revealed his belief in the masculinity of citizenship: "Is it our resignation as men that dame Hubertine asks of us? Let her say it frankly" (Villemot).

Women were granted the vote in 1944 and thus presumably designated abstract individuals. At the time, de Gaulle used the franchise as a way of repairing national unity after the divisions of the Occupation and the disgrace of the collaborationist Vichy regime. The inclusion of women signaled a return to universalist principles; differences, even the most intractable of them, now seemed amenable to incorporation. Simone de Beauvoir warned a few years later that the vote had been only a partial victory: "[A]bstract rights [. . ] have never sufficed to assure to woman a definite hold on the world; true equality between the sexes does not exist even today" (150). But even the issue of abstract rights was not fully resolved; indeed the "true equality" Beauvoir sought was elusive precisely because the difference of sex seemed to pose a limit to abstraction.

Giving women the vote recognized them as individuals, but not quite. Although the constitution of the Fifth Republic considered them eligible for office, it was extremely difficult for women to clear the hurdles political parties put in their path. It was one thing to cast a ballot (to be a citizen), it seemed, quite another to represent the nation (to be a representative). The pressure to keep women out of the body of the nation (to refuse to allow it to be divided symbolically) was enormous and effective. In the years from 1945 to 1997, women never constituted more than six percent of the deputies in the National Assembly or three percent of the Senate. And despite feminist 
agitation for quotas during the 1970s and 1980s (especially within the Socialist Party), politicians seemed unable to find a way to correct the persistent discrimination women experienced. ${ }^{3}$ (Those women who did dare to run for office recounted the opposition they faced within their own parties. It was like declaring war, one reported. Others told of receiving obscene threats and insults from those who were supposed to be their comrades. Another confided that she was never treated like a "real" deputy because she was a woman. Many more took the hint and stayed away [Sineau 54-55].) Feminist protest in these years called for politicians to live up to the promises of de Gaulle's constitution - "the law guarantees to women equal rights with men in all spheres" - but the difference of sex continued to be held against them. It became increasingly clear that this was not just a matter of male politicians protecting their monopoly - or quasi monopoly - of elective office at a moment when it was publicly called into question, but a problem with the way in which the underlying principle of universalism was understood. If women were to become abstract individuals, fully interchangeable with men as representatives of the nation, then the issue of sexual difference had to be directly addressed. Instead of allowing it to stand for that which had to be excluded (antagonism, division, difference) - in this way functioning as what Slavoj Žižek calls universalism's "obscene underside" - differences of sex had to become a characteristic of universalism itself ("Da Capo" 220).

The exploration of this possibility took place in a context in which - on the eve of the bicentennial of the first revolution-the original universalist principles were being turned to ever more conservative uses. Indeed, the vehement reassertion of republican universalism began in the 1980s as a response to the emergence of what are usually called the "new social movements" - precursors to the identity based politics of the 1990s. The questions of difference, and discrimination based upon it, loomed large despite a national policy of studious ignorance: among other things, statistics were not kept on minorities in the population (published census data contains no ethnic classification, only information about whether a person's grandparents were not French born), or on the results of elections by gender. (In this way the illusion of national unity is preserved by counting everyone only as individuals.) Unlike the United States, where affirmative action was the policy offered to end years of discrimination based on gender and race, France resisted "differentialism" in the name of republican universalism. An antidiscrimination law passed 
in the 1970s to punish racist utterances, but the turn to positive action was firmly resisted in the name of universalism. Public debate prevented any measures taken in favor of immigrants, and a decision by the Constitutional Council in 1982 ruled out special treatment of women as a way of correcting discrimination against them. The classification of individuals as members of groups was impermissible, the Council ruled, citing (in the case of quotas for women candidates in elections) both the constitution of 1958 and Article 6 of the Declaration of the Rights of Man and Citizen (1789), which reads, "All citizens are equal before the law and are equally admissible to all offices, places and public employments, according to their capacity and without other distinction than that of their virtues and talents" (full text cited in Marques-Pereira 174).

The problem was, of course, that social distinctions did prevent some individuals from enjoying equal access to "all offices, places, and public employments." There were two groups for whom equal access was particularly difficult: those of North African origin and/or Islamic affiliation who were designated "immigrants," though many were several generations removed from any "immigrant" experience, and women. What these two groups had in common was a difference deemed irreducible (not susceptible to assimilation or abstraction). North African "immigrants" by definition were outside French cultural boundaries; even if they were born in France, even if they were secular, they were outsiders because of a presumed association with Islam. Women signified internal difference and irreparable antagonism. In both cases, these qualities were taken as antithetical to universalism. How could those exhibiting such qualities be capable of speaking in the name of the general will? What would it take for North Africans and women to be incorporated into the body politic without fracturing its unified representation?

The answer to the immigrant question offered by politicians in the early 1990s set the context within which feminists articulated their demands for parité. The immigrant question was particularly fraught because of the arrival on the political scene in 1983 of JeanMarie Le Pen and his ultranationalist Front National. (Le Pen's continued electoral success - he won fourteen percent of the vote in the presidential election of 1988 and more than that in 2002-was taken to be symptomatic of a "crisis of representation." The discussion of this crisis provided an important opening for parity.) Le Pen's position was that North Africans should be sent back to their countries of origin and he managed (manages increasingly) to acquire impressive 
electoral support. Among those who opposed him were advocates of a more multicultural approach, one that would recognize the complex ethnic composition of France, and those - the majority - who insisted that universalism could accommodate-could integrate-the troubling challenge posed by the growing North African population. The official doctrine of intégration was articulated in 1993 in revisions of the nationality code and in a set of laws that came to be known as the Pasqua Laws (named for the right-wing Minister of Interior). Intégration was premised, not surprisingly, on abstract individualism. To become a citizen, a report from the Haut Conseil à l'Intégration argued in 1993, meant enjoying full freedom of private communal association, while rejecting "the logic of there being distinct ethnic or cultural minorities, and instead looking for a logic based on the equality of individual persons" (qtd. in Favell 70). France might be culturally diverse-liberty of association guaranteed this - but politically, it was homogeneous - individuals were equal before the law, their rights conferred and protected by the laws of the state. Intégration did not hold up the old standard of cultural assimilation (according to which one had to embrace not only the values of secular universalism, but speak, eat, dress and "look" French), but it did demand a singular national identification. For purposes of politics, only one collective identity was admitted: that of being French (Favell 17). ${ }^{4}$

This scheme of integration actually did little to solve the problem of "immigrants" in French society. In fact, it drew attention away from the social and economic realities faced by North Africans living in France and made difficult any representation of their collective fate. Those who spoke for the group were seen as advocating a "multiculturalism" at odds with universalism. And others who simply went about their own business were still subject to discrimination. Even as citizens, North Africans are treated as strangers by virtue of their ethnicity (dubbed "Islamists" even if they are secular); they are assumed to be foreigners whose interests are tangential, irrelevant, or dangerous to the collective interest of "France." Needless to say, such people can hardly be considered eligible to represent the nation. As in the case of women, even after they were granted citizenship, North Africans were not counted as fully individual. They remain associated with a difference that cannot be abstracted.

The reaffirmation of the principles of republican universalism in the context of the immigration question did not finally address the problem of the relationship of France's increasing cultural diversity to national unity; it served instead to deny the existence of discrimi- 
nation. For if all individuals were equal, how could there be discrimination? Yet, if there were discrimination (based on attributions of group identity), how could it be rectified if these attributions could not be taken into account? For those concerned with the relationship between the social and the political, this raised troubling issues: Had the principles of 1789 outlived their usefulness in the 1990s? Or was there a way to adapt them to new exigencies without losing the very desirable equalizing effect abstraction could have? Was there some way to change the notion of the individual, expanding its capacity for abstraction to include differences once thought to be irreducible? It was on the terrain of sexual difference that feminists tried to grapple with these questions.

The movement for parity began formally in 1992, with the publication of a manifesto by Françoise Gaspard, Claude Servan-Schreiber, and Anne LeGall entitled Au Pouvoir, citoyennes! Liberté, Egalité, Parité. The authors were veterans of the feminist attempts in the 1980s to improve women's position in the political sphere. They were also outspoken partisans of greater representation for immigrants and their families. Gaspard and Servan-Schreiber had coauthored a book in 1984, La Fin des immigrés, arguing for a more pluralist definition of French culture and politics. Gaspard had been the mayor of Dreux until she was unseated by the National Front, and a Socialist Party deputy from the department of Eure et Loir (see Gaspard, Une petite Ville). Servan-Schreiber was a journalist, Le Gall a feminist. Their long experience made them skeptical of the capacity of male politicians to voluntarily accommodate feminist demands. What was needed, they believed, was a law that would both force such accommodation and change the terms that defined what representation was. Law had the power not only to overcome the resistance of politicians, but also to alter the symbolic structures upon which social organization rested. Law had the power to replace what was deemed a false universalism with a true one.

Parite was conceived entirely within the terms of the discourse of abstraction so critical to French republicanism. If the abstract individual was supposed to be without physical or social marking, then why was it that [white] men made up more than ninety percent of those representing the nation? This was not, parity advocates maintained, an accident of history, but the result of the fact that universality and masculinity were taken to be synonymous. Or, as historian Michelle Perrot put it, the universal "is in fact a fig leaf that only covers over the masculinity that has served to exclude women from 
the government of the polity." Since all humans come in two sexes, the consistent exclusion of one sex was a sign of discrimination. And if there was discrimination, the individual was not a universal figure. The republican theory of representation (which these feminists granted) was based on the idea that individuals were interchangeable units, made identical by their capacity for reason; no other traits mattered. Women's ability to reason had long been established (in laws granting equal education at the end of the nineteenth century and in enfranchisement in 1944), but they had yet to be deemed worthy of representing the electorate, and by extension the nation. They were not, in other words, considered identical to all other individuals, not universal enough to transcend the difference of their sex. The exclusion of women suggested there might be other exclusions too, since the representative individual turned out to be a set of particularities. The absence of women serving as representatives, then, indicated a corruption of republican universalism; the representatives of the nation were not only financially corrupt (as various scandals in 1988 and 1989 had revealed), but - through the practice of discrimination, which introduced the difference of sex as a criterion for holding office - they had corrupted the principle of representation itself.

If women were to achieve the status of individuals, nothing less than full equality was required. Dismissing quotas as inadequate, the paritairistes called initially for a fifty-fifty division of seats. Fifty-fifty was not a quota, they argued, but a reflection of the fact that, whatever other qualities they might have, individuals were always sexed. Anatomical difference was universal, but the meanings attributed to it were social and cultural. These meanings were the source of inequality. Until now, the paritairistes reasoned, the universal abstract individual had been figured in terms of symbols that associated reason and abstraction with masculinity, passion and the concrete with femininity. In order to extend the possibility of abstraction to women, anatomical difference had to be separated from its symbolizations. The way to do this was to insist on the duality of the human (not the difference of the sexes): the universal individual was man and woman.

This was not the same as the nature/culture, sex/gender argument that American feminists first used and then deconstructed, because no inherent meaning (upon which gender was constructed or to which it could be referred) was attributed to anatomical duality (indeed, biology was also understood to be "cultural" - it was concrete, not abstract, a discourse attempting to account for and to resolve the 
brute "fact" of the anatomical difference of sex). Servan-Schreiber put it clearly in a discussion of parity with the feminist group, Dialogue des femmes. ${ }^{5}$ First, she refuted the idea that parity was a way to recognize "the true nature" of women, their essential "difference." The point was not to defend any special "women's interest" or to bring a uniquely feminine capacity to law-making ("We would fall here into a differentialist discourse that I myself in no way share" [9]), but rather to make women plausible representatives of the nation. Insisting on the duality of the human was a way of claiming the equal right of women to represent humanity. "Human kind is an entity that stands on two legs - two legs which are part and parcel of a single body and yet not interchangeable; in light of this, what we want is the political recognition of such duality." While "difference" came laden with all sorts of cultural assumptions about the inescapably biological capacities and characteristics of women and men, Servan-Schreiber thought, "duality" avoided those associations. Women and men were not, in one sense, interchangeable; if they were, women would be subsumed and thus effaced by dominant males. The argument against such obliteration (and thus against discrimination) required that women be distinctly visible. Equality implied a recognition of difference-in this case that the human was man and woman-in order to qualify women as individuals and eliminate their sex as a consideration. Only by insisting on the necessary duality of the human could a truly inclusive individualism (one in which sex no longer mattered) exist. "It is paradoxical, but interesting to argue," commented philosopher Françoise Collin, "that it was universalism that best maintained the sexualization of power, and that parity attempts, by contrast, to desexualize power by extending it to both sexes. Parity would thus be the true universalism" (in Projets féminists 103). ${ }^{6}$

Duality was not an argument about complementarity, nor was it about the necessary heterosexual foundation of society. Rather, men and women simply existed as two human types; laws that attributed necessary meanings to the abstraction of this duality had prevented women from acting as representatives in elected assemblies. This was a violation not of nature - nature had nothing to do with it - but of the principles of democracy. For the authors of Au Pouvoir, citoyennes,

[D]emocracy is a universal aspiration; universality encompasses women and men. There is, therefore, no representative democracy if representation is not equal (paritaire). Today, the under-representation of women in elected assemblies is so constant in its disproportion that it reveals a 
deficit of thought and consequently of law. Because of this disproportion, a new democratic contract is needed. The word "contract" presumes equality between the contracting parties. Only the adoption of a parity law will insure that this equality is real. (Gaspard et al. 130)

Anticipating objections from those who saw parite as the tip of a differentialist or communitarian iceberg à l'américaine, the authors denied that they were treating women as a "class" or a "social group." There was no "women's interest" at stake because women cut across all interest groups. Electing women would not mean introducing a separate, unified element into the legislatures; women could be expected to be found in every party, on all sides of contested issues. It was "pernicious," they said, to put women on the same plane as classes, social categories, or ethnic communities:

Women are not a minority. They are everywhere. They are found in every class, in all social categories. They are Catholic, Protestant, Jewish, Muslim, agnostic. They cannot be compared to pressure groups [. . .] demanding better representation. [. . .] Women are neither a corporate entity nor a lobby. They constitute half of the sovereign people, half of the human race. (166)

Blandine Kriegel also rejected the equation of women with a minority group. "Femininity is a universal," she wrote, "and just as when one is masculine one is considered human, so when one is feminine one is human." The law on parity was meant to implement not a fixed relationship of sexual difference (now rendered irrelevant), but the abstract, hence universalist, principles of democracy.

For the parity movement, passage of a law was critical for achieving this end since only a law would provide the conditions within which a resymbolization of the relations between women and men would become possible. As Gaspard put it:

Social and political prejudices deduced from differences based on anatomical sex persist in relations of power (to men's benefit) and are expressed, notably, in politics. In the field of political decision-making it is clear that an implicit "order" of men exists. The conquest of strict equality for women with men in political assemblies - whether national or local-is thus also symbolic. ("De la parité" 42)

The route to passage of such a law, however, was not easy. Ironically, not because it was hard to mobilize political opinion (the paritairistes 
proved to be brilliant strategists and in less than a decade forced the hand of reluctant politicians with, among other things, poll results that showed more than seventy percent of the electorate, with no difference between women and men, in favor of passage of a fiftyfifty law), but because it proved difficult to maintain the philosophical integrity of the argument. The original paritairistes distinguished between anatomical dualism and sexual difference; the one was an abstraction - the assertion of the neutrality, the essential meaninglessness, the disembodiment of sexed bodies - the other was substantive, it designated social, cultural, and psychical attempts to establish meaning. They were two different registers of thinking. The problem was that it was hard to keep the registers apart because they were related but not identical. It was difficult to abstract bodies from the meanings attributed to them, especially since those meanings usually offered the duality evident in nature as their justification. So the invocation of "men" and "women" called up the very symbolization the paritairistes wanted to change - the abstraction of anatomical duality became the concrete phenomenon of sexual difference.

However precise their formulations, the proponents of parity were often misheard. Gaspard's careful statement- "Our struggle for parity should be situated in the perspective of an equality of the sexes founded not on the denial of difference, but on a difference that has been overcome, that is, recognized the better to be evacuated from the sites where it produces inequality" - was taken by some of her critics to be an endorsement of the idea that biology determined social behavior ("La Parité" 13). Some feminists charged that the paritairistes were betraying decades of attempts to repudiate the connection between nature and gender, and some republicans accused them of trying to substitute American multiculturalism for French universalism. Most disappointingly, some supporters of the movement themselves justified it in essentialist terms. In its conceptualization a form of humanistic egalitarianism, parity became - in the minds of its critics as well as some of its supporters - nothing other than identity politics. $^{7}$

In my book, I track the slide between the registers of abstraction and embodiment (Scott 2005). My point here is that the kind of philosophical distinction the paritairistes offered could be elusive. Although the grass-roots demonstrations and petitions they so brilliantly organized effectively translated philosophical argument into practical politics by (among other things) studiously avoiding any call for a separate women's interest and insisting instead on fairness 
and equality of access to elective office, there were inevitably feminists who rallied to the cause in the name of the essential difference of women. This slippage does not seem to have mattered too much until 1998, when in the context of fierce debates about a domestic partnership law for homosexuals, philosopher Sylviane Agacinski (wife of then Prime Minister Lionel Jospin) published a book that collapsed the two registers into one. In her hands, duality became difference and the heterosexual couple replaced the abstract individual as the proper unit of citizenship.

I won't rehearse here the story of the campaign for what became the PACS - the pact of civil solidarity. It is a long and fascinating tale that centered around the question of whether or not gay couples could be defined as families, that is, as kinship units having the right to establish lineages by adopting (or in the case of lesbian partnerships, bearing) children. Nor will it be surprising if I simply mention the fact that all parties to the debates made their case in terms of universalism. Everyone agreed that this was not to be a law for gay people only; the stain of "differentialism" had to be avoided at all costs. Thus, the law that eventually passed recognized gay couples as "concubines" - unmarried sexual partners committed to a life in common and sharing a bed. But everyone did not agree about whether these concubines could constitute families. To qualify for that status, marriage was required, or, if not marriage, heterosexuality. Thus, although the law was supposed to be universal in its applicability, it made a distinction between gay and straight concubines. (Gay couples can neither adopt nor have access to reproductive technologies, although those options exist for unmarried heterosexual couples.) A higher principle was thought to be at stake here, another kind of universalism: the universal law of sexual difference. "The symbolism of gender, of masculine and feminine, exists in all human societies; it is the way culture makes sense of the sexed nature of the living species," wrote sociologist Irène Théry, a fierce opponent of the PACS (178). If human-made law had to abstract people from particular social categories, Théry seemed to be saying, gay couples could be absorbed into the category of "concubines"; but this law could not override the law of sexual difference, which was pre-political, not biological, but cultural and for that reason fundamental for human self-understanding. As such, it was a difference that could admit of no abstraction for political purposes. Anthropologist Françoise Héritier spoke of sexual difference as the primary difference: "It is the fundamental opposition that allows us to think at all. For thinking means, first of 
all, classifying, and classifying means discriminating, and the fundamental form of discrimination is based on the difference between the sexes." According to Héritier, "[A]ll our modes of thought and our social organization are founded primarily on the observation of the difference between the sexes. It is impossible to maintain reasonably that this difference can be displaced upon the homosexual couple." Despite Claude Lévi-Strauss's refusal to endorse these arguments (he suggested that the issue was not the enduring facts of culture, but a political struggle about establishing natural referents for social organization), what sociologist Eric Fassin has labeled "the anthropological illusion" persisted. ${ }^{8}$ It became the cornerstone not only of attacks on the PACS but also of defenses of the law and its exclusions. Sexual difference, embodied by the heterosexual couple, was taken to be the symbolic mastercode of humankind. "The institution of marriage is itself that of the difference of sex" (Théry, "La fausse"). Sexual difference was an "objective" and "universal" reality (Anatrella). ${ }^{9}$ Agacinski repeated these arguments in her book, Politique des sexes, ostensibly a brief for parité but in fact a strong argument against homosexual families. She grounded her support for parity in what she took to be the irrefutable facts of nature: not only were there two sexes, but theirs was a necessary relationship of heterosexuality, based in procreation. ("Same-sex attraction is accidental, it is a sort of exception that, however frequent, confirms the rule" [Agacinksi 108].) This couple was necessarily interdependent-procreation and the survival of the species required it - and it was the basis for systems of kinship and lineage in all human societies. Social sexuality, she insisted, was a reflection of biological sexuality. And so children had the "right" to know that they were the product of a mother and father, a woman and a man. Changes in family law must be limited to those measures that do not deny the rules of natural procreation (even if the child is cloned or conceived in a test tube). This means, above all, that two parents of the same sex is an oxymoron, and the law must not contradict natural fact.

In the past, Agacinski continued, the relationship of the couple was constructed hierarchically; in the family and in politics, women were subordinate to men. But now there was an opportunity to change that, to fully realize the longheld dream of equality between the sexes. Women and men were different, but their roles were complementary; together they embodied the human. And so, she wrote, it was time to bring this notion of complementarity into the political realm-because it was scandalous not to and because modern de- 
mocracy required it. It was time to share power equally, to acknowledge that the sovereign people came in two sexes, to introduce complementarity into the notion of sovereignty. "Parity must stand for the mixed nature [la mixité] of national representation in its totality so as to represent the mixed nature of the nation's humanity in its totality" (Agacinksi 196). This explicitly did not mean dividing the national representation by gender, for it did not assume that men represented men and women, women. Rather (and here she was in agreement with the original paritairistes), Agacinski argued that the nation was a fiction realized through political representation and that parité was concerned with the reconfiguration of that representation. "The equal representation of women and men must therefore be a pertinent figure for what a 'people' is universally, that is to say, a people made up of men and women" (202). Those who worried that figuring "le peuple" as double (man and woman) would fracture national sovereignty were wrong. Mixité was precisely not divisiveness or fracturing, Agacinski insisted, but a kind of unity, the unity exemplified by the reproductive couple merging to conceive a child. Parity would institute mixité, a notion borrowed from coeducation and denoting the equality of different, complementary types. "To think of mixité," Agacinski promised, "is to accept two versions of man and to represent humanity as a couple" (101).

It was in the translation of anatomical dualism into a heterosexual couple that Agacinski departed from the thinking of the founders of the parity movement. The idea of the couple served to join her two concerns: she could oppose homosexual families and support political equality for women in the name of the mixité of the heterosexual couple. The standard for equality became marital complementarity in families as well as in politics. Same-sex institutions - whether parliaments or marriages - were simply not acceptable because they could not realize this equality.

In the context of the PACS debates in 1998-1999, and the apparently deep-rooted fear of "unnatural reproduction" that it played upon, Agacinski's vision of parité became the dominant one, eclipsing the finely wrought arguments that had marked the early parity campaign. If essentialist possibilities always hovered around those arguments, they did not drive or define them. It was Agacinski's book that brought them out. In her hands, parity became an endorsement of normative heterosexuality as well as of the homophobic impetus that informed the government's version of the PACS. It may well be that her book helped to convince legislators to pass both laws (it was 
she, and not Gaspard, Servan-Schreiber, and Le Gall, whose writing was repeatedly cited in the National Assembly and Senate debates); it is certain that her version of parite became the dominant one in the months and years that followed the book's publication. Intellectuals who should know better - among them, most recently, Jacques Derrida and Elisabeth Roudinesco - have taken Agacinski's views to be representative of the movement, and so they worry that the results of the parity law may be the reification of a certain "maternalism" (57). In a final irony, it may be that Agacinski accomplished exactly the opposite of what the paritairistes intended. While they sought a way to make anatomical duality compatible with the discourse of abstraction (gaining the equality of women and men as individuals), she moved the conversation to another register - to the discourse of gender or sexual difference. She replaced the abstract individual with the embodied couple. And as a result, she reinscribed sexual difference as incompatible with (antagonistic to) abstract individualism, reaffirming the conception that, since 1789 , had been the basis for the exclusion of women from politics.

How are we to understand this story? Where does it fit in the great philosophical debates about universalism that have preoccupied so many of us over the course of the last decade? Is my story a confirmation of Judith Butler's claim that sexual difference cannot ever be separated from its historical and social formulations? Is it the case that no amount of abstraction can extricate it from its symbolizations? Here is Butler:

Precisely because the transcendental does not and cannot keep its separate place as a more fundamental "level," precisely because sexual difference as a transcendental ground must not only take shape within the horizon of intelligibility but structure and limit that horizon as well, it functions actively and normatively to constrain what will and will not count as an intelligible alternative within culture. Thus, as a transcendental claim, sexual difference should be rigorously opposed by anyone who wants to guard against a theory that would prescribe in advance what kind of sexual arrangements will and will not be permitted in intelligible culture. The inevitable vacillation between the transcendental and social functioning of the term makes its prescriptive function inevitable. (148)

Or should we take Slavoj Žižek's alternative, offered in the name of Jacques Lacan? For Lacan, Žižek writes, 
sexual difference is not a firm set of "static" symbolic oppositions and inclusions/exclusions, but the name of a deadlock, of a trauma, of an open question, of something that resists every attempt at its symbolization. Every translation of sexual difference into a set of symbolic oppositions is doomed to fail, and it is this very "impossibility" that opens up the terrains of the hegemonic struggle for what "sexual difference" will mean. ("Class" 110)

Aside from the fact that these are not exactly arguments about the same thing, I think the founders of parité would suggest - with some deference, because they do not claim to be philosophers - that it is too soon to know what the effects will be of the law passed in June 2000. And, they would add, it is the law after all that will matter in the end. (The wording of the law, of course, is free of any of Agacinski's justifications for it.) That law requires that women candidates constitute half of electoral lists in municipal and regional elections, in elections for the Corsican Assembly, for the part of the Senate that is elected proportionally, and for the European parliament. The lists for the Senate and the European parliament must alternate candidates by sex; those for municipalities (of more than 3,500 inhabitants), regional assemblies, and the Corsican Assembly must have three women and three men in each group of six. Those lists that do not comply will be disqualified. For the legislative elections, where there are single candidates not lists, parties that do not respect parity in the designation of candidates must forfeit government financial support for their campaigns (Marques-Pereira 158-60).

The first test of the new law came in the municipal elections of March 2001. The predictions that women would not want to run, were unqualified, or simply had no time, proved wrong. Thousands of women ran for municipal council seats; many of them had never before participated in politics. In the end, parité produced the desired results: women are now 47.5 percent of municipal councilors (in towns with populations over 3,500) as compared to 25.7 percent in 1995. With this change came an undeniable reinvigoration, a sense of new possibility in the political field. True, hopes for a quick revolution were dashed during the legislative elections of 2002 when, in the face of the threat posed by Jean-Marie Le Pen (who had come in second in the first round of the presidential elections), the major parties refused to comply with the law, choosing instead to forfeit government subsidies. (The feeling that incumbents stood a better chance than newcomers, but also that women couldn't hold off the 
rightist menace as well as men could, were the reasons given for this decision.) Women are now only about twelve percent of the deputies in the National Assembly, and there is some talk about whether, at this level, parity will ever be enforceable. But it is also clear that the law will not be overturned. Most politicians think it is too popular to touch.

If the law stays in place, it will provide a ready lever for feminist pressure, and it may gradually do the work of resymbolization that the paritairistes thought it would. They believed that although law seemed to reflect existing beliefs and practices, it in fact had the power to change them. Eventually the new order, slowly and sometimes imperceptibly brought into being by the law, would be taken to be self-evident and a reflection of the nature of things. Servan-Schreiber put it eloquently in an address to a large gathering of women in 1994.

I will end by reminding us that the rights of women, all the rights obtained in the course of history, have arisen from struggles that ended with the inscription of these rights in the law. Today, those rights seem to us to be self-evident: we have forgotten, fifty years after the institution of universal suffrage, that for many, many generations, women's right to vote did not seem so self-evident, not at all. I am convinced that one day it will be said that parity was instituted by law precisely because it, too, was "self-evident." ("Pourquoi" 34)

Should Servan-Schreiber be right, then at least in the realm of political representation, women will someday be considered equally susceptible to abstraction, individuals fully capable of representing the nation. At that point, universalism - French universalism - will have achieved its intended end.

To project this ending, of course, requires thinking that French universalism, as mythologized in the 1990s, will remain in place indefinitely, continuing to set the rules of politics. It is not at all clear that this will be the case. The battle for parity, as for the PACS and for the rights of North African "immigrants" to be redesignated as "French," can also be seen as a set of pressures for the democratization (dare I say it, the Americanization) of French political life. And this would involve not the abstraction of difference, but its recognition, and thus a more pluralistic vision of the nation. This is not the kind of outcome the founders of the parite movement had in mind. They were firmly committed to universalism and to the idea that abstraction was indeed a key to equality; the possibilities for democra- 
cy, they believed, were best realized through some version of abstract individualism. The questions now are whether the implementation of parity will affect the workings of democracy in any way beyond the increased access of women to public office and how that effect will be achieved. That is a question that awaits its answer in the years to come. I end, then, on an inconclusive note, for the story of parité awaits its conclusion not in the judgments of philosophers, but in the contingencies of history.

\section{NOTES}

1. This essay was given as the first annual Naomi Schor Memorial Lecture at Yale University on September 24, 2003. Thanks to Debra Keates and James Swenson for help with translations from the French. It was published in differences 15:2 (Winter 2004), pp. 32-53.

2. On these developments, see Rosanvallon.

3. See Jenson and Sineau.

4. See also Rancière, "Citoyenneté" 55.

5. Dialogue des femmes was a group that met regularly in the early 1990s to which speakers were invited. Their minutes were circulated as mimeographed typescripts. Copies from some sessions are at the Bibliothèque Durand in Paris in the parité files.

6. Projets féminists published a special double issue in 1996 containing transcriptions of a year-long seminar devoted to parity. Sessions consisted of brief presentations by several speakers followed by questions and discussion.

7. See, for instance, Amar.

8. For the Lévi-Strauss comment, see Borillo, Fassin, and Iacub 110.

9. See also Borrillo and Lascoumes. 


\section{JOAN WALLACH SCOTT}

\section{LITERATURE}

Agacinski, Sylviane. Politique des sexes. Paris: Seuil, 1998.

Amar, Micheline, ed. Le Piège de la parité: Arguments pour un débat. Paris: Hachette Littératures, 1999.

Anatrella, Tony. “Une précipitation anxieuse.” Le Monde 10 Oct. 1998.

Balibar, Étienne. "Ambiguous Universality." differences: A Journal of Feminist Cultural Studies 7.1 (1995): 48-74.

Birnbaum, Pierre. The Idea of France. New York: Hill and Wang, 2001.

Borillo, Daniel, Eric Fassin, and Marcela Iacub. Au-delà du PACS: L'expertise familiale à l'épreuve de l'homosexualité. Paris: PUF, 1999.

Borrillo, Daniel, and Pierre Lascoumes. Amours égales? Le PACS, les homosexuals, et la gauche. Paris: La Découverte, 2002.

Butler, Judith. "Competing Universalities." Butler, Laclau, and Žižek 13681.

Butler, Judith, Ernesto Laclau, and Slavoj Žižek. Contingency, Hegemony, Universality: Contemporary Dialogues on the Left. London: Verso, 2000.

de Beauvoir, Simone. The Second Sex. New York: Vintage, 1952.

Derrida, Jacques, and Elisabeth Roudinesco. De quoi demain . . . Dialogue. Paris: Fayard, 2001.

Dialogue des femmes. Meeting of 18 Oct. 1992. Typescript.

Fassin, Eric. "L'illusion anthropologique: homosexualité et filiation." Témoin 12 May 1998: 43-56.

Favell, Adrian. Philosophies of Integration: Immigration and the Idea of Citizenship in France and Britain. Basingstoke: Palgrave, 2001.

Gaspard, Françoise. “De la parité: genèse d'un concept naissance d'un mouvement." Nouvelles Questions Feministes 15.4 (1994): 29-44.

- - _. Une petite Ville en France. Paris: Gallimard, 1990.

_ - _. "La Parité, pourquoi pas?" Pouvoirs 82 (1997): 115-25.

Gaspard, Françoise, and Claude Servan-Schreiber. La Fin des immigrés. Paris: Seuil, 1984.

Gaspard, Françoise, Claude Servan-Schreiber, and Anne Le Gall. Au Pouvoir, citoyennes! Liberté, Ègalité, Parité. Paris: Seuil, 1992.

Héritier, Françoise. "Aucune société n'admet de parenté homosexuelle." Interview with Marianne Gomex. La Croix Nov. 1998.

Jenson, Jean, and Mariette Sineau. Mitterrand et les Françaises: Un rendez-vous manqué. Paris: Presses de la Fondation Nationale des Sciences Politiques, 1995.

Kriegel, Blandine. “Non, la mariée n'est pas trop belle.” Le Monde. 17 Feb. 1999.

Levy, Darlene, Harriet Applewhite, and Mary Johnson, eds. Women in Revolutionary Paris, 1789-1795. Chicago: University of Chicago Press, 1980.

Marques-Pereira, Bérengère. La citoyenneté politique des femmes. Paris: Dalloz, 2003. 
Perrot, Michelle. "Oui, tenter cette expérience nouvelle." Le Monde 25 Feb. 1999.

Projets féminists 4-5 (Feb. 1996).

Rancière, Jacques. "Citoyenneté, culture, et politique." Mondialisation, Citoyenneté, et Multiculturalism. Ed. Mikhaèl Elbaz and Denise Helly. Québec: Presses de l'Université Laval, 2000. 55-68.

- - - . "Post-Democracy, Politics and Philosophy." Angelaki 1.3 (1994): 17178 .

Rosanvallon, Pierre. Le peuple introuvable: Histoire de la représentation démocratique en France. Paris: Gaillimard, 1998.

Schor, Naomi. "French Feminism is a Universalism." Bad Objects: Essays Popular and Unpopular. Durham: Duke UP, 1995. 3-27.

Scott, Joan W. Parité: Sexual Equality and The Crisis of French Universalism. Chicago: University of Chicago Press, 2005.

Servan-Schreiber, Claude. "Pourquoi la parité est nécessaire et légitime." Après-demain 380-81 (Jan-Feb. 1996): 33-34.

Sineau, Mariette. "Les femmes politiques sous la Ve République-à la recherche d'une légitimité électorale." Pouvoirs 82 (1997): 54-55.

Théry, Irène. "Le contrat d'union sociale en question." Esprit 10 (1997): 159_ 211.

- - - . "La fausse bonne idée du contrat union sociale, c'est de tout mélanger." Le Monde 25 Nov. 1997.

Tixerant, Jules. Le Féminisme à l'époque de 1848 dans l'ordre politique et dans l'ordre économique. Paris: V. Girard et E. Brière, 1908.

Villemot, Émile. Le Gaulois 7 June 1877.

Žižek, Slavoj. "Class Struggle or Postmodernism?" Butler, Laclau, and Žižek 90-135.

- - - "Da Capo senza Fine." Butler, Laclau, and Žižek 213-62. 